\title{
A Choice of Development Strategy of Chinese Economy from the Perspective of the Relationship between Comparative Advantage and Competitive Advantage
}

\author{
Xiaoming Qiao \\ Journal Editorial Department, Yunnan Normal University, Kunming, 650092, China
}

Keywords: Comparative advantage, Competitive advantage, Relationship, Economy development

\begin{abstract}
Given the problem in China's economic development, the comparative advantage or competitive advantage has been debated in the academic circle. This paper tries to draw a basic conclusion from the relationship between the two theories. The theories of comparative advantage and competitive advantage are not completely opposed, which are differentiated and complementary. Therefore, the two theories should be applied in the formulation of China's economic development strategy simultaneously to give full play to the existing comparative advantages and cultivate new competitive advantages. Only in this way can the international competitiveness of China be continuously improved.
\end{abstract}

\section{Battle of Comparative Advantage and Competitive Advantage}

There is still much controversy in academic circles about what theory to guide China's participation in international division of labor and international trade. The typical representation is the argument of comparative advantage and competitive advantage. The typical representative of the strategy of supporting comparative advantage is Yifu Lin, who believes that the enterprise with the ability of self-generation is the microcosmic basis for the healthy operation of the economy. In the environment of the market economy, whether the enterprise has the ability of self-birth depends on whether the enterprise does production and operation according to the comparative advantage. This can extend the choice of different products in the same industry, and can also be extended to many industries. Therefore, our country should give full play to the advantage of labor resources and develop labor intensive industries. He also pointed out that if we do not follow the strategy of comparative advantage, we will lead to the contradiction between the malformed industrial structure and the abundant labor resources structure which violated the comparative advantage, so that large scale population cannot share the benefits of economic development and fall into poverty. To a certain extent, modern science and technology have excluded natural resources from the competitive factors [1].

\section{Relationship between Comparative Advantage and Competitive Advantage}

Many domestic scholars in the analysis of what the theory of the guiding principles of China's economic development, often will comparative advantage and competitive advantage in opposition, the formation of either this or that relationship. However, according to the theory of comparative advantage and competitive advantage, the relationship between them is not completely opposed to each other, but is closely related to each other.

\subsection{Basic Content of Comparative Advantage and Competitive Advantage}

The theory of comparative advantage was formed by Ricardo's theory of the absolute superiority of Smith, and was later supplemented and perfected by Heck Sher and Ohlin. The theory reveals the difference factors of technical factors and the factors of resource endowment difference determined by comparative advantage. This theory is a long-term guidance to each country's international division of labor all countries participate in the international division of labor according to the 
principle of comparative advantage, to form the comparative advantage structure of foreign trade. In general, developing countries lack capital and technology, and have the advantages of rich natural resources and labor resources. If countries have free trade according to the principle of comparative advantage, more benefits can be gained [2].

The theory of competitive advantage was put forward by Michael Potter. He believes that enterprises can build their competitive advantages on two different levels. The low level competitive advantage is a kind of "low cost competitive advantage", while the high level competitive advantage is a kind of "product differentiation competitive advantage". Product differentiated competitive advantage is based on continuous investment and innovation in equipment, technology, management and marketing, to create differentiated products that are more suitable for customer needs. In the theory of national competitive advantage, Potter's "Diamond System" model includes four main factors: production factors, demand conditions, performance of related industries and supporting industries, business strategy, enterprise structure and competitors. Through its "Diamond System" model, Potter explained how an enterprise (or industry) of a country can achieve lasting international competitiveness.

\subsection{Relationship between Comparative Advantage and Competitive Advantage}

The comparative advantage and the competitive advantage are not completely opposite, although there are differences, the relationship between them is very close [3]. First look at the differences between them. First, the theoretical premise of the two is different. The theory of comparative advantage takes completely competitive market as the theoretical premise, and the theory of competitive advantage takes the incomplete competitive market as the theoretical premise. The latter is more in line with the current reality than the former; secondly, the research angle is different. The theory of comparative advantage considers from a global perspective that a country can increase its welfare and increase production efficiency and resource allocation level in the world if it only works according to the principle of comparative cost. From the perspective of the state, the theory of competitive advantage considers how to make a country get more benefits in the trade activities, improve production efficiency faster, and occupy a more advantageous position in the international division of labor. Third, the scope is different. The competitive advantage theory holds that the competitive advantage depends mainly on the innovation mechanism of a country, and it depends on the day after day and enterprising spirit of the enterprise. If enterprises dare to innovate and compete actively, a backward country may become a country with competitive advantages.

Because of the multipurpose nature of international trade, it is difficult to expect to explain all trade phenomena only through a theory. The phenomenon of international trade and intra industry trade under the condition of similar factor endowment structure, which is explained by the theory of competitive advantage, belongs to the category of "new trade theory" [4]. The comparative advantage and competitive advantage of the concept of opposition, after the negation of the former is wrong, it may lead the country (or region) against their development strategy of comparative advantage in economic development, endangering their own industrial competitiveness and overall competitiveness development. To give full play to the comparative advantage of the economy is the basis for the state to create and maintain the competitive advantage of the industry. In general, competitive advantage will strengthen the comparative advantage of a country and enlarge the comparative advantage. Comparative advantage is the basis of competitive advantage, competitive advantage made step by step according to the economic environment and the economic development situation, choose to have a comparative advantage in the product or industry to further expand the competitive advantage than the cultivation of no comparative advantage products or industries more feasible, lower cost. At the same time, comparative advantage can only be realized through the exertion of competitive advantage. If the regional industry has comparative advantage, but has no competitive advantage, its comparative advantage cannot be realized. 


\section{Strategy Selection Problem of China's Economic Development}

From the above two theories, we can get the basic conclusion that comparative advantage and competitive advantage are not opposites, though they are different, but the links between them are also very close. The development strategy of China's economy should be selected according to the actual conditions of the country, and the following is a detailed analysis.

\subsection{Continue to Give Full Play to the Comparative Advantage to Cultivate the Basis for the Competitive Advantage}

The development of any country's foreign trade will be restricted by its domestic resource endowment and comparative cost, which is undisputed. China is a developing country, and the socialist market economy is still in its primary stage. From the perspective of China's current economic development, production and trade in accordance with traditional comparative advantages cannot be abandoned too early, which will still have important practical significance in the future. The main reasons are as follows: first, the export of the current full development of capital and technology intensive industries is still constrained by the input of factors. Chinese as a developing country, if the full development of capital and technology intensive products exports, will face serious constraints of input factors, these factors including capital, technology, personnel etc. Continue to play the comparative advantages of factor endowment and comparative cost as the core of the traditional for the emerging, capital intensive industries (or technology) accumulation of capital and technology, to cultivate family enterprises, technological innovation, breakthrough the bottleneck input factors of production and promote the traditional labor-intensive industries gradually lay the foundation for upgrading. Secondly, to continue to play the traditional comparative advantage is beneficial for China to improve the efficiency of the allocation of resources on the macro level. Compared with most countries in the world, the high cost of Chinese capital and technology is relatively scarce, and labor is relatively abundant, low cost, and a country's economic competitiveness and it provides the goods and services cost is closely related to premature abandonment of traditional comparative advantages, will only lead to More haste, less speed.

From the perspective of China's economic practice, China's economic development strategy deviated from the principle of comparative advantage in the early days of the founding of the People's Republic of China and the reform and opening policy. It ignored the national conditions of scarcity of capital, abundant labor or even excess, and gave priority to the development of capital intensive industries. As a result, after a short period of achievement, insufficient capital and lack of employment have become the bottleneck of economic development, and the economy is seriously unbalanced and setback. At that time, South Korea, Taiwan, Indonesia and other countries and regions relied on the development of labor intensive industries to achieve economic breakthroughs. China has lost a good time for economic development. Since the reform and opening. China has adjusted the traditional economic development strategy and began to achieve remarkable achievements in accordance with the principle of comparative advantage. This shows that the principle of comparative advantage is adapted to China. And from the present point of view, China's trade partners are mostly developed countries and regions. According to Krugman's view, if the ratio of capital labor between countries is quite different, all trade will be built based on comparative advantage. From this point of view, China should follow the principle of comparative advantage.

However, the following problems should be paid attention to in giving full play to the comparative advantage. First, it is a system problem. Yifu Lin (1999) pointed out that when making the choice of technology and industry, enterprises can make a correct response to comparative advantage. There is a price structure that can fully reflect the relative scarcity of various production factors. However, because the transaction and operation of Chinese elements are usually achieved through the way of non-marketization. The factor market is controlled by the government. Therefore, factor prices tend to go far from the equilibrium price of the market, or far below the market equilibrium price. Such a system cannot reflect the real price of the elements, and it is easy for enterprises to misinterpret when 
choosing industries with comparative advantages.

Second, it is the issue of trade friction. A few countries in most of the countries in the negotiations on the day the advantage, considering the complexity of the international environment and domestic pressure from specific sectors of the developing countries, developed countries will continue to open up the market, continue to make those who have no competitive industries is not realistic. The pressure from the domestic industry associations and the high cost of arranging career changes for textile workers did not completely give up the developed countries, which exacerbated the friction of textile trade.

\subsection{Cultivate Competitive Advantage}

As a big country, China is obviously not a wise choice to realize economic development if the comparative advantages play a role in the world. The practice of developed countries tells us that although the economic development of a country cannot go beyond the stage, but beyond the time, in the way that Lester plantation, relying on competitive advantage to promote foreign trade and economic growth, can enhance the international competitiveness in a relatively short period of time.

China is not satisfied with the establishment of its foreign trade strategy according to the simple comparative advantage principle, and it is necessary to transform the comparative advantage into the competitive advantage. Specifically, the following strategies can be adopted: the role of the government is attached. The government can increase the quality of the essential elements of the country by opening the economy to the outside world. In accordance with the "narrow band" principle, the government can choose the appropriate key industries as appropriate as possible to provide appropriate policy support. The history of economic development in the world indicates that the competitive advantage of high-tech industry is often created by people rather than born. The government can avoid mistakes by careful decision in supporting high-tech industries. China high-tech industry should be "limited objectives, focus, market oriented, give full play to the advantages of high-tech products" principle, determine the development of information, biological medicine, new materials, consumer electronics and household appliances in the field of export to promote the export of high-tech products China. In terms of market selection, the state has focused on cultivating many industrial sectors with high technology content and good export prospects, to drive the optimization and upgrading of the national industrial structure to gain national competitive advantage.

In addition, there are many problems in the process of following the strategy of comparative advantage in China. In addition, China's labor-intensive industries with comparative advantages have been encountering escalating trade frictions. Therefore, if we follow the strategy of comparative advantage, these disadvantages will happen.

From the difference between comparative advantage and competitive advantage, the theoretical hypothesis of competitive advantage may be more in line with the real world. In the contemporary economy, "invisible hand" and "see through hand" are all playing a role. The international market competition is subject to the Dual Restriction of market price competition mechanism and enterprise mechanism. Modern enterprises have become the main body of resource allocation and the main body of competition in economic life. Its international competitive behavior has great influence on the occurrence and development of international trade. Its advocacy of non-price competition and innovation strategy is in line with the development trend of international competition in the world today. Therefore, the theory of competitive advantage is still in place.

Therefore, properly nurturing industries that do not have the advantage now, we can avoid the negative effects that only follow the comparative advantage. There are two ways in this process: first, transform the traditional resource intensive and labor-intensive industries with modern technology, and transform them into resource technology intensive, resource capital intensive, labor technology intensive and labor capital intensive ones. To promote and optimize the original industrial structure, the two is to foster competitive advantages of new industries, introduce or subsidize the development of new technologies, and establish industries that are suitable for global competition. 


\section{Conclusions}

Through the above discussion, we can draw the basic conclusion: the theory of comparative advantage and competitive advantage is not completely opposed, they should be differentiated and complementary. The theory of competitive advantage is not a negation of comparative advantage, both of which are an explanation of the international trade of different phenomena. Therefore, when formulating China's economic development strategy, we should combine the two theories to give full play to existing comparative advantages and cultivate new competitive advantages to continuously improve our international competitiveness.

\section{References}

[1] Li Min, Huang Qin, Zheng Yinglong. Objectives and Paths of Wage Collective Bargaining under the Analysis of Competitive Advantages: Based on Comparative Research of China and Europe [J]. Human Resources Development of China, 2015(5): 82-89.

[2] Sun Nengli. Transformation from Comparative Advantage to Competitive Advantage-A Way to Improve Regional Agricultural Competitiveness [J]. Asian Agricultural Research, 2011, 3(11): 5-8.

[3] Jin Ping, Liu Yan. Comparative Advantage, Competitive Advantage and Industrial Policy: A Study of Chilean Experiences [J]. Journal of Latin American Studi, 2013, 35(1): 14-20+79-80.

[4] Zhou Jie, Li Xiaoyu, Xue Youzhi. Can Servitization Create Competitive advantage for Manufacturing Compames-A Comparative Study of Local Companies and International Companies [J]. 2015, 37(10): 66-78. 